\title{
Promoting the English language learning through the $u$ se of effective andragogical strategies
}

\section{Promover el aprendizaje del idioma inglés mediante el uso de estrategias}

\author{
andragógicas efectivas
}

1 Marcia Magally Paredes Acosta Pontificia Universidad Católica magally.paredes@educacion.gob.es

2 Ana Jazmina Vera de la Torre https://orcid.org/0000-0001-8239-2375 del Ecuador, Ambato-Ecuador, Posgrados Universidad Técnica de Ambato, Facultad de Ciencias Humanas y de la Educación, Carrera de Pedagogía de los Idiomas Nacionales y Extranjeros. Ambato-Ecuador aj.vera@uta.edu.ec

3 Ruth Elizabeth Infante Paredes $\quad$ (iD) https://orcid.org/0000-0002-5035-761X Universidad Técnica de Ambato, Facultad de Ciencias Humanas y de la Educación, Carrera de Pedagogía de los Idiomas Nacionales y Extranjeros. Ambato-Ecuador ruthinfantep@uta.edu.ec

$4 \quad$ Alba Paulina Hernández Freire

https://orcid.org/0000-0002-1618-8330. Universidad Técnica de Ambato, Facultad de Ciencias Humanas y de la Educación, Carrera de Pedagogía de los Idiomas Nacionales y Extranjeros. Ambato-Ecuador albaphernandezf@uta.edu.ec

Artículo de Investigación Científica y Tecnológica

Enviado: 06/12/2021

Revisado: $13 / 12 / 2021$

Aceptado: $12 / 01 / 2022$

Publicado:08/03/2023

DOI: https://doi.org/10.33262/concienciadigital.v6i1.4.1983

\section{Cítese:}

Paredes Acosta, M. M., Vera de la Torre, A. J., Infante Paredes, R. E., \& Hernández Freire, A. P. (2023). Promoting the English language learning through the use of effective $\begin{array}{llll}\text { andragogical strategies } \quad \text { ConcienciaDigital, } & 6(1.4), & 20-35 .\end{array}$ https://doi.org/10.33262/concienciadigital.v6i1.4.1983

CONCIENCIA DIGITAL, es una Revista Multidisciplinar, Trimestral, que se publicará en soporte electrónico tiene como misión contribuir a la formación de profesionales competentes con visión humanística y crítica que sean capaces de exponer sus resultados investigativos y científicos en la misma medida que se promueva mediante su intervención cambios positivos en la sociedad. https://concienciadigital.org

La revista es editada por la Editorial Ciencia Digital (Editorial de prestigio registrada en la Cámara Ecuatoriana de Libro con No de Afiliación 663) www.celibro.org.ec 


\section{Palabras}

claves: adultos, andragogía, experiencia, aprendizaje, estrategias

\section{Keywords:} adults, andragogy, experience, learning, strategies.

\section{Resumen}

Introducción. Este trabajo de investigación implementó estrategias andragógicas para el aprendizaje del inglés en docentes de la Unidad Educativa "El Oro" de la ciudad de Ambato. Objetivo. Promover el aprendizaje del idioma inglés mediante el uso de estrategias andragógicas efectivas. Metodología. En esta investigación cuasiexperimental, la misma se ejecutó con la participación de 30 docentes (adultos) de diferentes áreas, quienes estaban automotivados para aprender y ayudarse mutuamente con el fin de actualizar su conocimiento del inglés. Se trabajó con dos grupos de la población objeto de estudio. Ambos grupos conformados por 15 docentes. El grupo experimental fue tratado con una propuesta de intervención que contenía estrategias andragógicas, tales como: la discusión, análisis, elaboración de proyecto, simulación, demostraciones y resolución de problemas; las que tenían una serie de tareas con enfoque comunicativo a través de la Plataforma Zoom a causa de la pandemia COVID-19. En cambio, el grupo control trabajó con actividades en línea quienes tenían documentos para llenar ejercicios gramaticales. Resultados. Ambos grupos respondieron a dos exámenes: el primero fue el pretest, antes de la intervención y el segundo o post-test después de la misma. Las medias de los dos exámenes fueron comparadas en el pretest y se evidenció que los dos grupos tenían un nivel bajo de inglés. En cambio, en el post-test, las medias de los dos grupos presentaron una notable diferencia por cuanto el grupo experimental, demostró una mejora considerable. Conclusión. Determina que las estrategias andragógicas ayudaron a los docentes a mejorar su aprendizaje del inglés. Se concluye que es de suma importancia la aplicación de estrategias andragógicas para mejorar su calidad profesional.

Abstract

Introduction. This research work implemented andragogical strategies for English learning in teachers of the Educational Unit "El Oro" in Ambato. Objective. Promote the English language learning through the use effective andragogical strategies. Methodology. It was used quasi-experimental research; it was executed with 30 teachers (adults) from different areas who were motivated to learn and help each other to update their knowledge of English. We worked with two groups of the population under study. 
Both groups were made up of 15 teachers. The experimental group was treated with an intervention proposal containing andragogical strategies, such as discussion, analysis, project elaboration, simulation, demonstrations, and problem solving, which had a series of tasks with a communicative approach through the Zoom Platform due to the COVID-19 pandemic. Nevertheless, the control group worked with online activities who had documents to fill grammar exercises. Both groups responded two tests: the first was taken before the intervention and the second or post-test after it.

Results. The means of the two exams were compared in the pre-test and it was evidenced that the two groups of teachers had a low level of English. On the other hand, in the post-test, that is, after the intervention, the means of the two groups showed significant difference, since the experimental group experienced a considerable improvement. Conclusion. In this way, it was determined that the use of andragogic strategies helped teachers to improve their learning of the English language. Therefore, it is recommended to apply andragogic strategies for better teachers' learning and thus, to improve their professional quality.

\section{Introduction}

The human being never stops learning during life, he is active and conscious, in constant relationship with the socio-cultural environment and with a fervent desire for new learning challenges, in front of the workplace, as well as in professional fulfillment. The adult student seeks immersion in education in different areas and one of them is the learning of the English language without considering age, it is proven that their learning is not limited by age (Gai, 2017). That is to say, the learning of the language, also, covers the adult, hence the importance of the andragogic strategies (Deveci, 2007), which promote their integral development, with the purpose of their constant motivation to learn to apprehend, learn to do, learn to be, and learn to develop critical and reflective thinking that drives their personal improvement in the social context where they develop.

Globalization urges to experience constant changes, where knowing a universal or global language such as English allows crossing borders and helps to be more competitive (Crystal, 2009), in recent years, the learning of the English Language becomes a global need in terms of communication. That is why this research is justified, it promotes the use of andragogic strategies for the learning of the English language. On February 17, 2016, a curricular reform took place with Ministerial Agreement No. MINEDUC-ME-201600020-A, indicates as mandatory the teaching of English from the first year of Basic 
General Education for the entire educational system. This regulation seeks that the student at the end of the Third Year of Baccalaureate, reaches a B1 level according to the Common European Framework, which means that he can read and write without difficulty (Ministerio de Educación, 2016).

That is, all schools and colleges guarantee the learning of the English language, it is the language considered as a common language (Crystal, 2009). In Ecuador English is learned as a foreign language. Globalization advances every day and being part of a global community where young people have the minimum obligation to know English, not as a tool, but as a mandatory resource to integrate into the world (Northrup, 2013). On the other hand, teachers must be sure to produce well the terminologies, phrases, quotes in English in front of young students who immediately verify their low level of English and lack of preparation (Dormer, 2013). Therefore, it is important to understand and communicate in English.

Currently, the Ministry of Education and the U.S. Embassy signed a letter of cooperation to support the strengthening of English language teaching in the country's fiscal educational institutions. Minister Creamer in the 2019 (U.S. Embassy \& Consulate in Ecuador, 2019), points out that the signing of the letter is the beginning of great opportunities for students. "This agreement reflects the positive and profound changes we are making in the educational model, benefiting our teachers and students. The mastery of English will allow them to have new life opportunities", in this sense the research focuses on strengthening the training in teachers through andragogic strategies in the learning of the English language to improve their professional quality and be in accordance with the globalized world, with this the teacher will be able to look for and select a good material to teach classes, in this way, the educational community will be better prepared (Ministerio de Educación, 2016).

Regarding the concept of andragogy according to Araujo and Veloza (2015), they catalog it as the science of teaching adults and is responsible for guiding the teacher in the teaching process through a participatory methodology and focused on the reality of adults. In relation to the learning of a language (English) is perceived as a necessity by adults to be immersed in a "digital society" linked to work, communication, or the search for information mention Ricoy and Alvarez (2016), a good teacher is in constant training to improve their professional quality. In this sense, the learning of the English language benefits the teachers, who are constantly updated and will be prepared to face the challenges of today's world.

On the other hand, the research problem fits the challenges of today's world. It is in the public domain that Ecuadorian professionals will at least have a level of English or sufficiency; however, the teachers of the El Oro Educational Unit have a self-perception of their low level. The teachers indicate that their problem is based on their reduced 
knowledge of vocabulary with which it is difficult for them to use the language to communicate, and this is evidenced in the results of the pre-test and the survey. Therefore, there is a lack of motivation for learning and updating their knowledge in this field. Additionally, teachers indicated that they have no knowledge of Andragogy; therefore, the feasibility of investigation is evident.

It should be noted that the methodology of adult learning focuses on how to plan, manage and direct educational praxis and enrich the general knowledge that the student possesses to complement them with new knowledge. What this research promotes is the development of interest in knowledge, how an adult person focuses on the process of learning the English language and methodological strategies that favor active participation in the development of communication skills. With this background, the research problem is reflected in the following question:

How does the implementation of andragogic strategies affect the learning of the English language in the teachers of the E.U.'El Oro'?

This research question is due to the need of teachers in the knowledge of the language, this is their reality. The teachers of the Educational Unit "El Oro" are part of the population under study. Therefore, they are the ones who are an active part of the proposal of the present investigation. Being a group of teachers who are in adulthood, it is essential that andragogic strategies are used in their learning.

Thus, the general objective of the research is as follows:

Implement andragogic strategies for the learning of the English language in the teachers of the EU'El Oro"

The specific objectives that will allow to meet the general objective are:

1. To base theoretically and scientifically the andragogic strategies and the learning of the English language in the teachers.

2. Diagnose the feasibility of implementing andragogic strategies that develop the learning of the English language in the teachers of the U.E El Oro“

3. Apply andragogic strategies that allow English language learning in teachers at the E.U.'El Oro"

4. Validate the proposal in two phases: the diagnosis and application respectively of the andragogic strategies for the learning of the English language in teachers of the EUEl Oro"

The methods used in the development of this research project were the quantitative method focused on the collection of information for the analysis and interpretation of results and the qualitative method based on discovering and refining research questions. 
In addition, direct descriptions were used to have a practical approach to the population involved. For the data collection, the survey technique was applied to verify the feasibility of the proposal and a pre-test to measure the level of the English language, to the 30 teachers of the EUEl Oro" in mention of the morning and evening sections.

Therefore, the direct beneficiaries of the elaboration of this study are 30 teachers of the EUEl Oro", in whom the andragogic strategies are applied to achieve the acquisition of knowledge and develop the communicative skills of the English language. Being the direct beneficiaries, it is of vital importance to create strategies to cement knowledge which help to complete their learning challenge in the following aspects:

- Awaken interest in learning using proactive, playful and dynamic techniques or activities.

- Create an environment of trust and sociability among the members of the group.

- Strengthen their artistic skills in the development of shapes, figures, drawings and more for language learning.

- Increase the lexicon of English for the fluent acquisition of language skills.

- Develop communicative skills by apprehending knowledge that improves both their oral expression and their written expression.

The teaching-learning process constitutes the fundamental way for the acquisition of knowledge, procedures, norms of behavior and values bequeathed by humanity; and that are passed down from generation to generation. Therefore, an analysis has been carried out on research that is closely related to this project in the approach of strategies to improve the learning of the English language as a foreign language, in the adult population, which maintain the importance and similar characteristics.

\section{State of the art and practice}

Since its beginnings in the nineteenth century and its popularization in the twentieth century (Ekoto \& Gaikwad, 2015), andragogy has been the subject of a short but significant empirical research by several researchers in various contexts. The following is a description of publications that are based on research on andragogy for Learning English. Wang and Storey (2015), investigate the possibility of whether Western andragogy is put into practice, in the teaching of English as a Foreign Language (TEFL) in China. The researchers modify and use for this study the Conti survey $(1983,2004)$, an instrument that is designed to promote the use of andragogy (adult learner-centered teaching) in any teaching environment, especially where teachers help pre-adults and adults learn. According to Wang and Storey (2015), westerners recognize a distinction between the education of children and the education of adults; therefore, it is of the utmost importance that teachers use the right method. 
The instrument is also designed to determine the general modes of instruction of teachers. They use andragogy to some extent, to personalize instruction, relate to the experience, assess students' needs, and create an educational climate. Their findings show that these teachers taught the lowest levels of taxonomy, which are characterized by rote learning, knowledge transmission, lectures, and focus on exams. These teaching methods are contrary to Western democratic approaches characterized by negotiating curricular priorities with students, awarding learning contracts instead of exams, and involving students in planning lessons. Therefore, they conclude that the Western style of teaching contributes to the communicative movement (or collaborative learning process) when it comes to learning a foreign language such as English.

In this sense, the research referred to above, has a lot to do with the present, because it is intended to improve the level of English of the teachers of the Educational Unit "El Oro". The population with which the intervention is intended to be carried out is made up of adults, therefore, what Wang and Storey (2015), indicate is considered: the English language with a communicative and collaborative approach in Western education. On the other hand, Veytia (2015), proposes the use of andragogic strategies such as: social networks, forums, blogs, wikis, chat and virtual portfolios in graduate students with the use of technological means. This proposal includes adult learning of the English language with a communicative and collaborative learning approach. In addition, synchronous and asynchronous activities that strengthen knowledge are included. Finally, it concludes that the proposed activities added to the feedback of the teacher significantly help the students and a remarkable acceptance of the project is clearly visualized, as well as, in the learning of the English Language. This is a qualitative and descriptive research, which does not show a theoretical review of the benefits of the use of andragogic strategies mediated by technology based on communicative processes.

The research that precedes is of great help, in addition to focusing on andragogic strategies, it also focuses on communicative and collaborative learning. That is what is desired with this research, an interaction and communication between the teachers of the Educational Unit "El Oro" through the use of the English Language. Therefore Veytia (2015), will be an indispensable prop to guide you, especially in the preparation of the proposal. In addition, cooperative learning will be proposed, this provides the right moments for interaction. At present, classes take place in an atypical context; through the Zoom platform due to the COVID-19 pandemic. In this context, that research largely serves as the basis for this.

Likewise, Deveci (2007), in his research carried out, states that significant experiences are the heart of learning in his research entitled "Andragogic and Pedagogical Orientations of Adult Students of English as a Foreign Language". Since it is the students themselves who construct the meaning of their experiences, teaching English for specific 
purposes needs to consider the characteristics of each student, which include their needs, desires, preferred learning styles, as well as anxieties. Only in this way will they be helped to improve learning and achieve greater well-being. Therefore, it is essential that ESP (English for Specific Purposes) instructors or, the study of English for specific purposes provide students with ample opportunities for andragogic participation.

Based on Deveci (2007), and with the explanations he provides in his research, it is understood that Andragogy dates to the time of Platon, who defended his educational ideas focused on adults and which was later used by Kapp in the 19th century. In this sense, his research has a lot to do with it, he works with adults to improve their level of English. In this case, there is a great advantage, and that is that the population is composed of education professionals who are very committed to their educational work and the need to update their knowledge. Within the same line Camacho \& Villacís (2017), in their article entitled 'Andragogic approach to enhance reading skills in students of English as a foreign language', aim to improve reading comprehension in intermediate level students of English as a foreign language in the age group of 18 to 40 years, in the Language Center of the Technical University of Ambato. As reviewed in previous research, this also focuses on the adult population.

In this research, the authors conducted quasi-experimental research where they measured the effect of the andragogic approach on reading. The subjects of this study were students aged 18 years or older who answered a survey related to the frequency of reading and the type of text preferred by them, as well as the strategies they used to understand an English text. During this work, reading strategies were taught and adapted to be applicable to adult learners. Finally, after teaching the students reading strategies with an andragogic approach, the results of the reading comprehension tests were measured to see if it had been improved. After the aulic intervention with the experimental group, positive results were evidenced in reading comprehension (Camacho \& Villacís, 2017).

Additionally, Maridueña et al. (2017), conducted research with the aim of using strategies for teaching English. This project was focused on university students who take the subject of English to strengthen their writing and reading skills. The population that participated in this research was made up of 103 students of the Systems Engineering career. Problems in language learning were detected; therefore, the proposal of new didactic strategies according to the adulthood of the students was needed. This research had a descriptive character for which the survey technique was used in data collection. The results show that most students have a low level of English. In addition, data were obtained that reflected that student have problems in reading comprehension. Due to these circumstances, the researchers propose an intervention in the classroom to apply active methodological strategies for adult students. These strategies are based on semantic 
language processing to improve writing and comprehensive reading skills, as well as vocabulary learning.

\section{Perspective of education and management of the learning process}

The verb to educate starts from an initial point when taking out or developing the potential, talent or capabilities of a person if there is the motivation to learn new knowledge. Today, humanity is in the digital age where intellectual capacity is expected to develop to its full potential. However, it also depends on the social system in which each person is, not everyone acquires a technological device to educate themselves, but we must not forget that, also, knowledge and learning are acquired through observation and imitation. This same situation is reproduced at the level of the school, its teachers, the curriculum (Barros, 2013).

Therefore, it is necessary for this to happen, there is talk of renewing a system of forming citizens who will be useful for society and the development of the nation that not only its objective serves society but, also, that they feel self-valued as important and capable people, "In fact, the learner can reach such a perfective degree of development, that he may be able to act habitually with moral rectitude and freedom" (Perelló, 2006, p.77).

Consequently, it is essential to make a deep analysis of the idiosyncrasies of the countries, and where and with what strategies you want to achieve maximum educational efficiency. Thus, at the end of the century the educational system declined with the governments of the day, and civil society, who were considered responsible for the failure of the educational area, for allowing the significant decrease in investments in education, deteriorates the quality, its infrastructure, the production of educational material, the teaching profession, vocational training and training, central and provincial management and administration, among others (Paladines, 2015).

\section{Andragogy and its processes in education}

The first time the term Andragogy was used was in 1833 when Alexander Kapp first used it, describing the educational practice used by Plato with his young and adult disciples. Later in 1920, Eugen Rosenback took up the concept by referring to curricular elements of adult education. Then, Eduard Lindeman generates ideas that guide adult teaching and in the execution of lines of action to form their thinking within informal instruction. In this way, he becomes the pioneer of the use of the concept of andragogy (Knowles, 2001). The name of the father of andragogy was granted to the American Malcolm Shepherd Knowles (1913-1997) for the contributions made and being a spearhead in the andragogic area. Knowles (2001) said that andragogy "... is a set of fundamental principles on adult learning that applies to all situations of such learning" (p. 3), and made a clarification, 
"andragogy is oriented towards adult education [...] not adult learning" Knowles (2001). Therefore, Andragogy addresses the aspect of how to help adults learn.

The adult, defined by Royal Spanish Academy in the 2018 as "saying of a living being that has reached the fullness of growth or development", for Knowles (2001) there are four viable definitions of adult (Castillo, 2018):

- Biological: They become adults, in the biological field, when they reach the age at which they can reproduce.

- Legal: They are adults when they reach the age set by a country to obtain the age of majority.

- Social: They are adults when they play adult roles such as joining the workplace.

- Psychological: They reach adulthood when they are recognized as such.

The three-level holistic andragogic model proposed by Knowles in the 2006 is composed as follows (Castillo, 2018):

\section{English Language Learning}

Learning is considered as the acquisition of new knowledge through experience, study and commonly the constant repetition of an activity. It reflects the importance it has in the formation and development of the personality (Castillo, 2018).

According to Pérez and Hernández (2014), "Learning is a process of appropriation of culture that is characterized by being active and meaningful, that is, it is not limited to the reproduction of learning content but to the deep understanding of it" (p.3).

The above implies recognizing a broad relationship between the capture of information and the imitation of such teaching, the behaviors that we acquire through observation are formed as such. Learning is a dialectical process of individual appropriation of social experience that extends throughout life.

For example, according to Pérez and Hernández (2014):

Learning is a dialectical process of appropriation of the contents and ways of knowing, doing, living together and being built in the socio-historical experience, in which relatively lasting and generalizable changes occur because of the subject's activity and interaction with other people, which allow him to adapt to reality, transform it and grow as a personality. (p.4) 


\section{Methodology}

For the development of the research, two methods of inquiry were used: quantitative and qualitative.

a) Quantitative Inductive Method. - allowed the collection of information for the analysis and interpretation of numerical results

b) Qualitative Method. - because it was used to discover and refine research questions, direct descriptions were employed to have a practical approach to the population involved.

In this regard Sampieri et al. (2015), states that the quantitative approach reflects the need to measure and estimate magnitudes of phenomena or research problems: how often do they occur and with what magnitude? The survey will be used as a technique to verify the feasibility of the proposal and a test to measure the level of the English language, which will be applied to the 30 teachers of the educational institution in mention of the morning and evening section, from initial education to baccalaureate, likewise for this research the SPSS data analysis and interpretation program was used.

In addition, this research was quasi-experimental, the target population participated in the implementation of the educational proposal of intervention that resulted from this research. Prior to the intervention process, a pre-test was applied; and, after it, a post-test was taken. This process was carried out with both the control group and the experimental group (Sampieri et al., 2015).

\section{Results}

The data obtained that are analyzed below, come from the exams that the teachers took before and after the implementation of the intervention proposal focused on andragogic strategies for learning English. In this virtue, the pre-test and post-test data of both groups that made up the population of this research were analyzed; that is, the control group and the experimental group. After the elaboration of the didactic proposal and having designed a pre-exam to measure the level of knowledge of the teachers in the English language, we proceeded to take a post-test; the results of which are presented below:

\section{Pre-test}

The analysis of the results of the pre-test was divided into two groups that correspond to both the control and experimental groups of the population object of this research. 


\section{Experimental group - pretest}

The pre-test was designed based on the general competences of the English language, according to the Common European Framework of the 2001; such as, listening and reading skills; as well as grammar and vocabulary, which were distributed in 20 questions.

Tabla 1

Comparación de medias del post-test

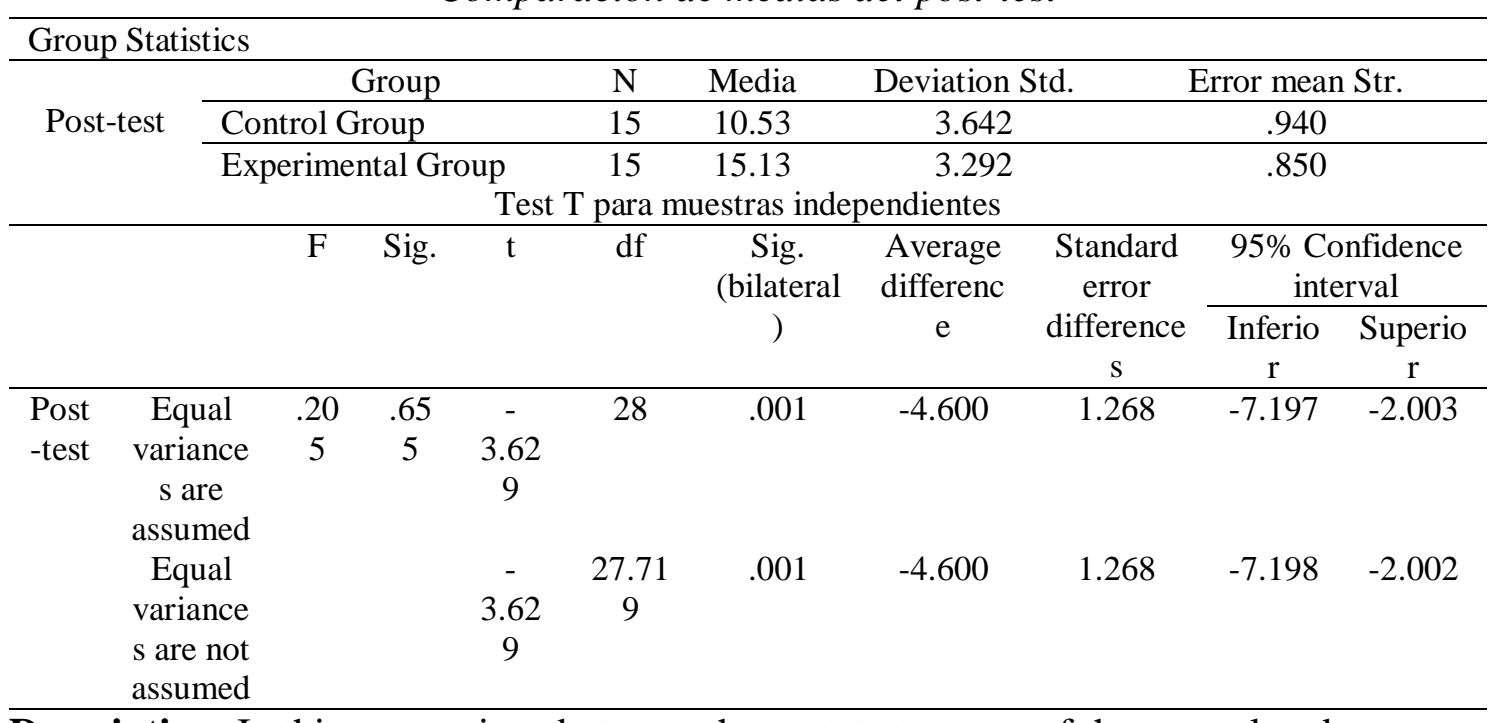

Description: In this comparison between the post-test means of the control and experimental groups.

In this comparison between the post-test means of the control and experimental groups, it is visible that the control group obtained a mean of 10.23 and the experimental group obtained a mean of 15.13. Although the expected score was 20, there is evidence that the experimental group improved their English language learning. Within the bilateral significance it is observed that .001 was obtained which is very close to .000 , this means that if there is a significant difference between the mean of the control group and the mean of the experimental group. Therefore, it is assumed that the control group maintained its low average, while the experimental group improved.

\section{Conclusions}

After the research process was carried out, the following conclusions emerged:

- The theoretical and scientific foundation of andragogic strategies and the learning of the English language in teachers was carried out from the theory of Knowles several andragogic strategies, as well as the theme of English language learning in adults were based on a literary review that was framed in a descriptive approach, based on pioneering authors in the branch of Andragogy as those contemporaries who have contributed to science of education (Castillo, 2018). 
- The diagnosis of the feasibility of implementing the andragogic strategies that develop the learning of the English language in the teachers of the E.U. El Oro" was carried out; To meet this objective, a survey of teachers was carried out that was focused on three main parameters such as: their need for professional updating, their level of English and their willingness to be part of the project. In this area, the teachers surveyed agreed on their need to update themselves in the English Language, their low level of it and their willingness to participate.

- The application of the andragogic strategies allows a learning of the English language in the teachers of the E.U.El Oro". Andragogic strategies such as discussion, analysis, simulation, projects, demonstrations, and problem solving, as well as a communicative approach, through tasks that were applied to teachers' learning.

- The validation of the proposal in two phases: the diagnosis and application respectively of the andragogic strategies for the learning of the English language in teachers of the EUEl Oro", was carried out. The last one was developed with the work and participation of the teachers of the Educational Unit "El Oro" in a virtual way due to the resilience caused by the COVID-19 pandemic. In this phase, the predisposition and active participation of education professionals was noted, who with great enthusiasm remembered and updated their knowledge in the language, to obtain optimal results.

- Therefore, the overall objective of this research was achieved. The learning of the English Language of the teachers of the Educational Unit "El Oro" was significantly improved through the implementation of andragogic strategies applied in the intervention process. In this way, it contributed to the professional improvement through an update of knowledge of the English Language, which is of necessity due to the demands of the current world and because it is a personal need of the professionals who work in the educational institution, where the population object of study of this research develops.

\section{References Bibliographical}

Araujo Lidueñas, LJ, \& Veloza Parra, DC (2015). Andragogía: guía metodológica para la enseñanza del inglés en la primaria acelerada. https://repository.unilibre.edu.co/handle/10901/8416

Barros Astudillo, T. J. M. (2013). Indicadores de calidad educativa en centros escolares del Distrito Metropolitano de Quito y propuesta de un modelo de calidad pertinente para el Ecuador. Donostia-San Sebastián, España: Universidad del País Vasco Universidad Central del Ecuador. 
Camacho, CH, \& Villacís, WV (2017). Enfoque Andragógico para potenciar la competencia lectora en estudiantes universitarios. Revista Publicando, 4 (12 (1)), 351-360. https://revistapublicando.org/revista/index.php/crv/article/view/665

Castillo Silva, F. (2018). Andragogía, andragogos y sus aportaciones. Voces de la Educación. https://hal.archives-ouvertes.fr/hal-02528598/

Crystal, D. (2009). English as a Global Language (2nd ed.). Cambridge University Press. https://doi.org/10.1017/cbo9780511486999

Deveci, T. (2007). Andragogical and pedagogical orientations of adult learners learning English as a foreign language. New Horizons on Adult Education and Human Resource Development, 21(3/4), 16-38. (n.d.). Sciepub.Com. Retrieved January 10, 2022, from http://www.sciepub.com/reference/131627

Dormer, J. E. (2013). Improving speaking accuracy through awareness. Journal of Adult Education, 42(1), 16-22. https://eric.ed.gov/?id=EJ1047326

Ekoto, C. E., \& Gaikwad, P. (2015). The impact of andragogy on Learning Satisfaction of graduate students. American Journal of Educational Research,3(11), 1378-1386. https://doi.org/10.12691/education-3-11-6

Gai, Y. C. M. (2017). Adult learners' experiences in learning English: A case study of two university students in Indonesia. IJOLTL Indonesian Journal of Language Teaching and Linguistics, 2(2), 131. https://doi.org/10.30957/ijoltl.v2i2.280

Knowles, M. S. (2001). Andragogía - El aprendizaje de Los adultos. Oxford University Press.

Maridueña Macancela, J., Ledesma Acosta, B. \& Astudillo Quiñonez, M. (2017). Vista de Worksheet design to develop audio and video English activities. (n.d.). Edu.ec. $\begin{array}{lll}\text { Retrieved January 2022, } & \text { 10, }\end{array}$ https://revistas.uees.edu.ec/index.php/Podium/article/view/44/44

Ministerio de Educación del Ecuador. (2016). Currículo 2016. https://educacion.gob.ec/curriculo/

Northrup, D. (2013). How English became the global language. Palgrave Macmillan. https://doi.org/10.1057/9781137303073

Paladines, C. (2015). Perspectivas de cambio en la Educación Básica y en el Bachillerato: Ecuador: 2007-2013. Praxis Educativa, 19(3), 13-31. http://www.scielo.org.ar/scielo.php?script=sci_abstract\&pid=S0328$97022015000300002 \& \operatorname{lng}=\mathrm{es} \& \mathrm{nrm}=$ iso 
Perelló, J. (2006). La filosofía de la educación como saber pedagógico. Sophia, 1(1), 129. https://doi.org/10.17163/soph.n1.2006.02

Pérez Ariza, K., \& Hernández Sánchez, J. E. (2014). Aprendizaje y comprensión. Una mirada desde las humanidades. Humanidades Médicas, 14(3), 699-709. http://scielo.sld.cu/scielo.php?script=sci_arttext\&pid=S1727-81202014000300010

Ricoy, M.-C., \& Álvarez-Pérez, S. (2016). La enseñanza del inglés en la educación básica de personas jóvenes y adultas. Revista mexicana de investigación educativa, 21(69), 385-409. http://www.scielo.org.mx/scielo.php?script=sci_arttext\&pid=S140566662016000200385

Sampieri, R. H., Collado, C. F., Pilar, D., \& Lucio, B. (2015). Metodología de la investigaci6n Cuarta edici6n. 191.86.244. Retrieved January 10, 2022, from http://187.191.86.244/rceis/registro/Metodolog\%C3\%ADa\%20de\%20la\%20Investig aci\%C3\%B3n\%20SAMPIERI.pdf

U.S. Embassy \& Consulate in Ecuador (2019, May 22). Fact sheet on new cooperation agreements between the United States and Ecuador -. https://ec.usembassy.gov/factsheet-on-new-cooperation-agreements-between-the-united-states-and-ecuador/

Veytia Bucheli, M. G. (2015). Estrategias Andragógicas Para Estudiantes De Posgrado A Partir De Procesos De Mediación Tecnológica. Atenas, 3(31), 45-54. https://www.redalyc.org/articulo.oa?id=478047207005

Wang, V. C. X., \& Storey, V. A. (2015). Andragogy and teaching English as a foreign language in China. The Reference Librarian, 56(4), 295-314. https://doi.org/10.1080/02763877.2015.1057680

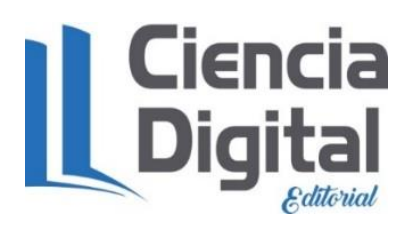


El artículo que se publica es de exclusiva responsabilidad de los autores y no necesariamente reflejan el pensamiento de la Revista Conciencia Digital.

\section{\Ciencia}

El artículo queda en propiedad de la revista y, por tanto, su publicación parcial y/o total en otro medio tiene que ser autorizado por el director de la Revista Conciencia Digital.
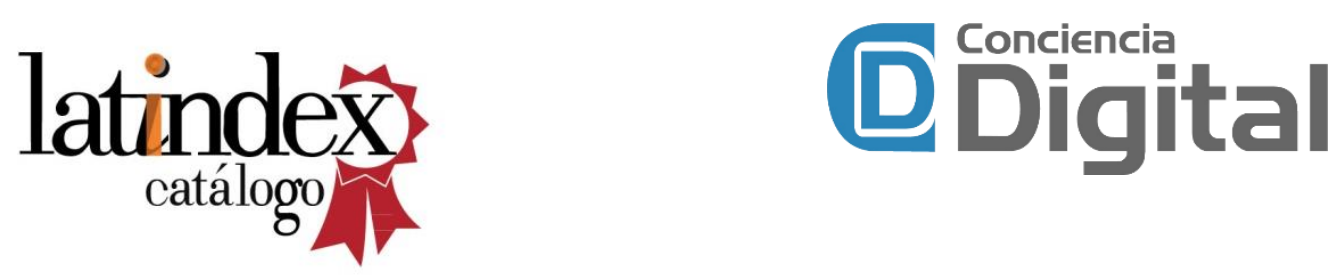

Indexaciones

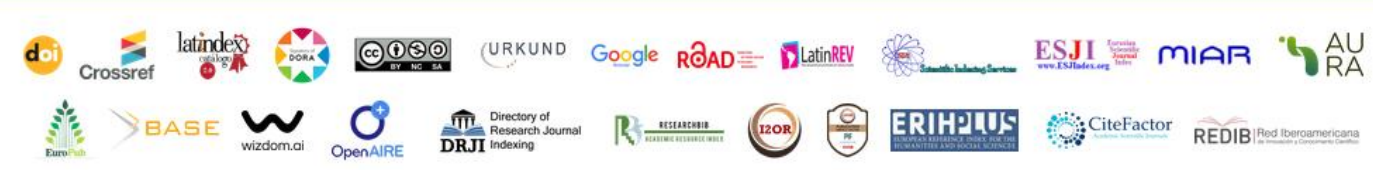

